\title{
Securities Litigation and the Housing Market Downturn
}

\section{Citation}

Allen Ferrell and Atanu Saha, Securities Litigation and the Housing Market Downturn, $35 \mathrm{~J}$.

Corp. L. (2009-2010).

\section{Published Version}

http://www.ilep.info/pdf/univ_of_iowa/2009/(A4)\%20Ferrell.pdf

\section{Permanent link}

http://nrs.harvard.edu/urn-3:HUL.InstRepos:32136185

\section{Terms of Use}

This article was downloaded from Harvard University's DASH repository, and is made available under the terms and conditions applicable to Open Access Policy Articles, as set forth at http:// nrs.harvard.edu/urn-3:HUL.InstRepos:dash.current.terms-of-use\#OAP

\section{Share Your Story}

The Harvard community has made this article openly available.

Please share how this access benefits you. Submit a story.

Accessibility 


\title{
HARVARD
}

JOHN M. OLIN CENTER FOR LAW, ECONOMICS, AND BUSINESS

\author{
SECURITIES LITIGATION AND THE \\ HOUSING MARKET DOWNTURN
}

Allen Ferrell and Atanu Saha

Discussion Paper No. 640

$5 / 2009$

Harvard Law School

Cambridge, MA 02138

This paper can be downloaded without charge from:

The Harvard John M. Olin Discussion Paper Series: http://www.law.harvard.edu/programs/olin_center/

The Social Science Research Network Electronic Paper Collection:

http://ssrn.com/abstract=1349971 


\title{
SECURITIEs Litigation AND THE Housing MARKET DOWNTURN
}

\author{
FORTHCOMING JOURNAL OF CORPORATION LAW
}

Allen FerRell* AND AtanU SaHA**

\begin{abstract}
This paper addresses one of the key issues - the foreseeability of the housing market downturn that began in September of 2007 and intensified in the fourth quarter of 2007 that must be addressed in assessing the extensive securities class action litigation that has been filed against financial institutions (and others) seeking to recover damages for investor losses arising out of the credit market crisis. We begin our analysis of this issue by first discussing the legal centrality of this issue to much of this litigation. We then turn to answer the question of when the housing market downturn became foreseeable by analyzing housing prices (regional and nationwide), housing sales, housing future contracts, and various market spreads such as the ABX triple A indexes. We conclude that these data are consistent with the view that the housing market downturn was in fact not foreseen by the market prior to the fourth quarter of 2007.
\end{abstract}

JEL: G18, G21, G28, K22, R21, R31

* Greenfield Professor of Securities Law, Harvard Law School, Ph.D. I would like to thank the John M. Olin Foundation in Law, Economics and Business at Harvard Law School for financial support. We gratefully acknowledge the research support of Mercy Arango and other staff members of AlixPartners. We like to thank Hal Scott and the participants at the Institute of Law and Economic Public Policy's 2009 Scottsdale, Arizona conference, "Recoveries for Victims of Securities Fraud," for their thoughtful comments

** Ph.D. Sr. Vice President \& Head of New York Office, Compass Lexecon LLC. Email: asaha@compasslexecon.com 


\section{INTRODUCTION}

It is undoubtedly the case that in many of the securities class action lawsuits that have been filed against financial institutions due to investors' losses in the wake of the recent financial crisis plaintiffs will be able to point to statistically significant, substantial price drops associated with firm-specific disclosures of writedowns and losses associated with securities whose value has been negatively impacted, perhaps dramatically so, by the downturn in the real estate market. ${ }^{1}$ But the existence of such a statistically significant, substantial negative price reaction is hardly the end of the analysis necessary to assess the claim that investor losses attributable to this price reaction result in recoverable damages. There are still the questions of whether, and if so when, disclosure deficiencies by financial institutions occurred, whether the requisite scienter associated with these disclosure deficiencies existed, and whether investors' losses are attributable to these disclosure deficiencies (this last issue being the requirement of loss causation in Rule $10 \mathrm{~b}-5$ causes of action). ${ }^{2}$

The key unifying issue that must be addressed in answering these questions, and perhaps the most fundamental of all the issues raised in the current wave of securities class action litigation arising out of the financial crisis, is the extent to which the downturn in the housing market, and the resulting financial institutions' writedowns and losses on securities with substantial real estate exposure, was foreseeable earlier in time. It is this foreseeability issue that our paper will focus on, including a detailed discussion of why this issue is legally central and our own analysis of housing data and market spread data that speaks to the foreseeability of the housing market downturn. We will focus on the foreseeability of the housing market downturn in our discussion and analysis beginning in 2006 as the vast majority of the class periods specified in the securities class action complaints filed against financial institutions begin in 2006 if not earlier. ${ }^{3}$ Indeed many of the securities class action complaints explicitly make the claim that the housing

\footnotetext{
${ }^{1}$ This is of course, as is all our observations, a generalization. Our goal in this paper is not to address any particular case or set of facts but to canvass the general securities class action landscape.

${ }^{2}$ For a discussion of the loss causation requirement see Allen Ferrell and Atanu Saha, "The Loss Causation Requirement for Rule 10B-5 Causes of Action: The Implications of Dura Pharmaceuticals v. Broudo," 63 BUSINESS LAWYER 163 (2007)

${ }^{3}$ See Jennifer Bethel, Allen Ferrell and Gang Hu, "Legal and Economic Issues in Litigation Arising Out of the Credit Market Crisis of 2000-2008,” forthcoming in Brookings.
} 
market downturn clearly became foreseeable in the fourth quarter of 2006 and, at the very latest, in the first quarter of 2007.

We will begin by briefly discussing in Part II the context in which much of the securities class action litigation against financial institutions is occurring. Specifically, much of the litigation is a response to the announced writedowns and losses that began in earnest in the fourth quarter of 2007 on securities, such as collateralized debt obligations (CDOs), asset-backed commercial paper (ABCP) and mortgage-backed securities (MBS), with exposure to the real estate market and the substantial investor losses that were incurred starting in the fourth quarter of 2007. It is the conjunction of these announced writedowns with investor losses that leads us to conclude that in many cases it is likely there will be statistically significant, substantial price drops associated with announced writedowns and losses.

Part III will then discuss in detail why the foreseeability of the housing market downturn is of great moment in assessing the legal soundness of many of the securities class action complaints. It is important to emphasize at the outset that when analyzing the foreseeability issue what is of primary legal importance is what the expectations of the market were concerning the likely future course of housing prices. That is to say, the fact that there were some observers that believed that housing prices might or would suffer a serious downturn does not by itself establish that the housing market downturn was foreseen by the market. There will always, after all, be observers who disagree with the market's expectations, whatever those expectations happen to be. The market's expectations of the likely future course of housing prices, as Part III will explain, will affect the analysis as to whether there was a disclosure deficiency that constituted actionable misconduct during the class period by a financial institution in the first place. The foreseeability of the housing market downturn will also affect, as Part III also explains, whether there was the requisite scienter (intentional or reckless misconduct) for any such disclosure deficiencies, and finally, even assuming misconduct with the requisite scienter, whether any of the losses suffered by the security holders of the financial institutions can satisfy the loss causation requirement.

Part IV will then discuss the relevant academic literature. As we will discuss, a basic finding of this literature is that housing prices are the primary explanatory factor in 
accounting for mortgage delinquencies and housing foreclosures, including the spike in delinquencies and foreclosures in 2007 and 2008. On a related note, several studies have found that the underwriting quality of mortgages are significantly less important as an explanatory factor for delinquencies and foreclosures, including the spike in 2007 and 2008. Indeed, several studies document that along several dimensions, such as borrowers' FICO scores, underwriting quality did not appear to deteriorate during the period leading up to the financial crisis.

Parts V and VI constitute the heart of our analysis. In these parts we turn to our own analysis of the foreseeability of the housing market downturn utilizing housing data in Part V and market spread data in Part VI. In terms of our housing data we first document that the substantial and sustained housing market downturn began in September of 2007 and intensified in the fourth quarter (October - December, 2007), rather than starting in the fourth quarter of 2006 or first quarter of 2007 despite common claims to the contrary. We document that this housing downturn was statistically quite unlikely if one estimates probabilities based on historical housing price data, the time series of which begins in January 1969. After discussing the housing price data, we then turn in Part V to an exploration of the variables that might explain the changes in monthly housing sales. We show that standard explanatory variables that have historically accounted for a substantial portion of the variation in changes in housing sales would have "predicted” positive housing sales during the September - November, 2007 period consistent with the view that the housing market downturn was unanticipated. We conclude Part V with presenting direct evidence of the market's expectations about future housing prices based on the pricing of housing futures traded on the Chicago Mercantile Exchange (CME). The CME housing futures market, it is worth emphasizing, is an institutional market in which the participants have their own money at stake. This evidence is consistent with the view that it was only at the end of 2007 and beginning of 2008 (December of 2007 and January of 2008) that the market anticipated a serious downturn in housing prices.

Part VI tackles the issue of the foreseeability of the housing market downturn from a different angle. In this part, we present data on various market spreads that impound information concerning market expectations as to the value of asset-backed 
securities and, specifically, asset-backed securities with substantial exposure to the real estate market. And, as with the housing data, we once again argue that this data are consistent with the view that the housing market was in fact not foreseen prior to the fourth quarter of 2007. We document for instance that the market pricing of triple A asset-backed securities only experienced a substantial fall in value in the second half of October of 2007. This is of particular note as many of the securities that resulted in substantial writedowns and losses were triple A or better (so-called “super seniors”).

Part VII concludes with some final comments.

\section{THE WRITEDOWNS AND INVESTOR LOSSES}

The fact that plaintiffs will likely be able to point, at least in many cases, to statistically significant, substantial price drops in reaction to a financial institution's announcement of a sizeable writedown can be surmised from simply comparing the quarters during which substantial bank writedowns and losses associated with real estate exposure occurred with the stock performance of the S\&P financial index, which consists of the financial firms in the S\&P 500 index, for the same time period. Such a comparison can be done by simply looking at Figures 1 and 2 .

Figure 1 below presents the distribution of bank writedowns and losses associated with subprime mortgage exposure, an important source of real estate exposure, through the end of the second quarter of 2008 as well as the actual aggregate losses for various financial institutions for this period. 
Figure 1

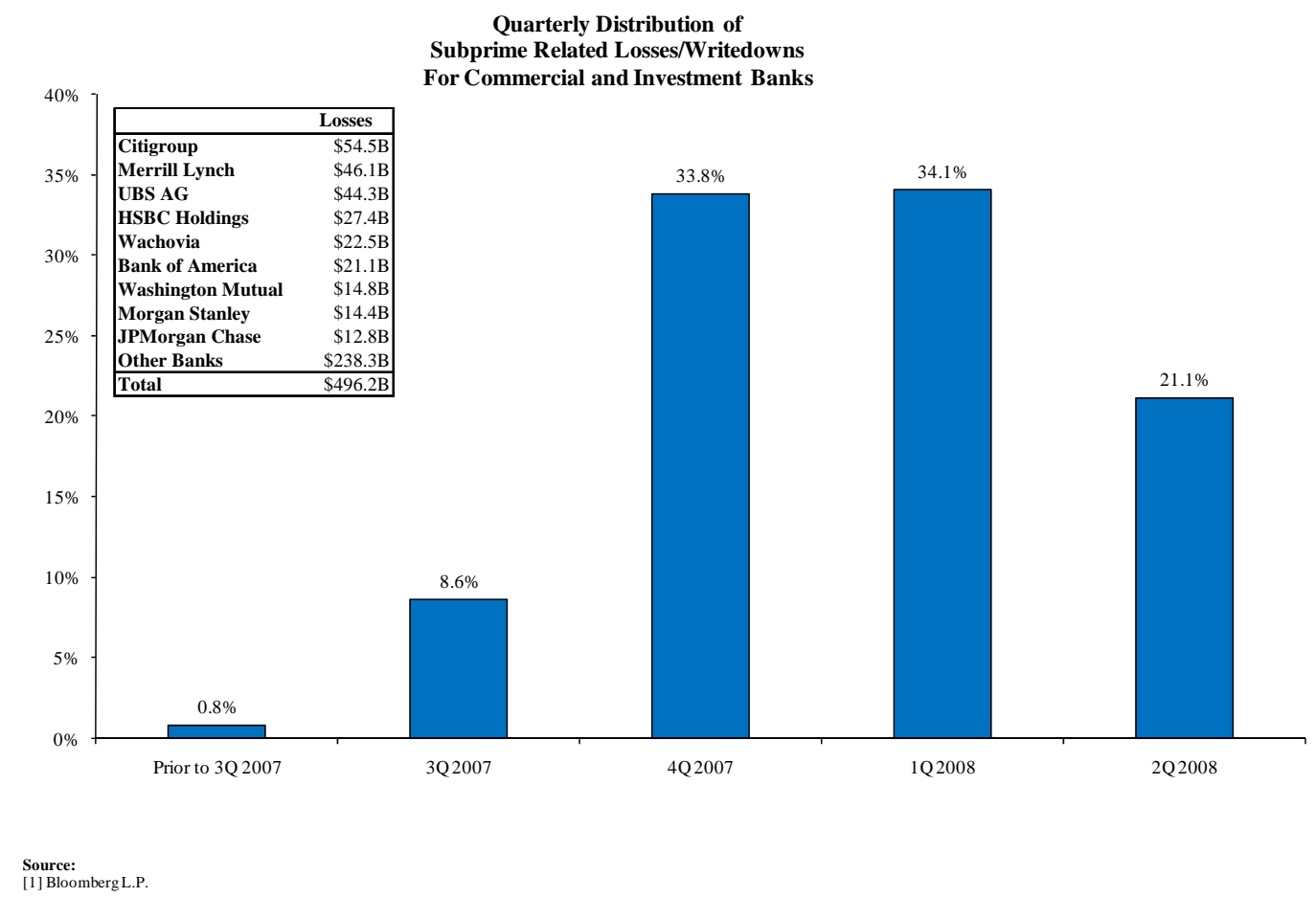

Figure 2 is a graph of the performance of the S\&P financial index through the end of the second quarter of 2008.

Figure 2

S\&P Financial Index

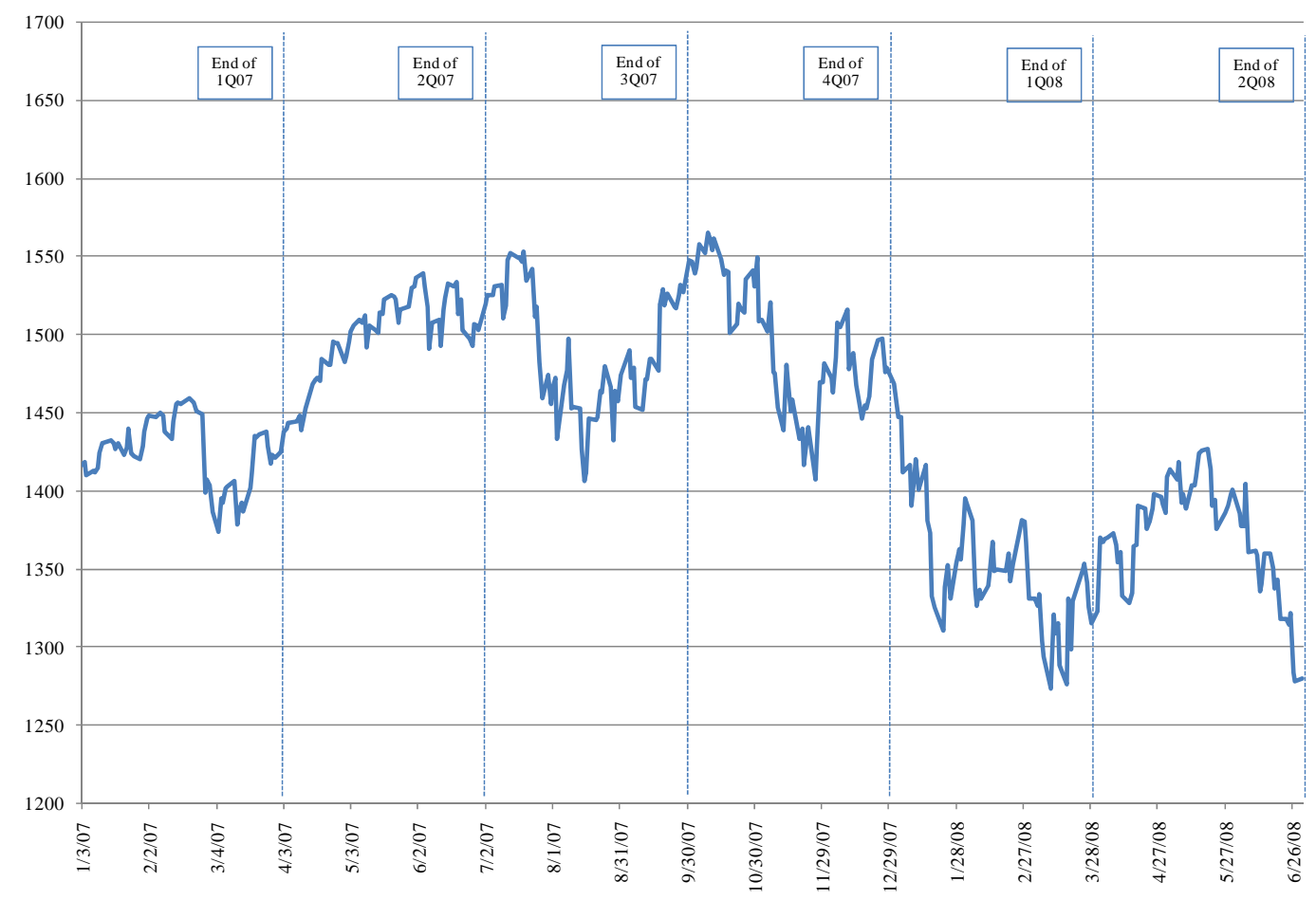


As is reflected in Figure 1, there were substantial bank writedowns and losses associated with subprime exposures to the housing market in the fourth quarter of 2007 and the first quarter of 2008 (with the writedowns and losses in the second quarter of 2007 being far smaller as a percentage of the total writedowns and losses and those prior to this quarter being de minimis). In terms of stock price performance, Figure 2 shows that for the two quarters with the bulk of the writedowns and losses (4Q, 2007; 1Q, 2008) financial institutions' stock prices suffered with the most substantial price declines not occurring during this time period until the first quarter of 2008.

\section{THE CENTRAL LEgAL IMPORTANCE OF THE FORESEEABILITY ISSUE}

The issue of when the housing market downturn was foreseeable lies at the heart of many of the legal issues at stake in the current wave of securities class action litigation arising from the financial crisis. If the housing market downturn that began in earnest in the fourth quarter of 2007 was foreseeable then at least arguably many of the losses that financial institutions suffered, and hence arguably their security holders' losses, were likewise foreseeable. These foreseeable investor losses, so the argument typically goes, supports, indeed substantiates, the claim that there were disclosure deficiencies by the financial institutions, the existence of the requisite (if the cause-of-action is Rule 10b-5) scienter for these disclosure deficiencies, and the existence of recoverable damages for investors.

We will now discuss how plaintiffs attempt to establish disclosure deficiencies, scienter and recoverable damages by relying on the contention that housing market downturn was foreseeable during whatever the purported class period happens to be. In so characterizing plaintiffs' claims and arguments we not do have any particular class action complaint in mind, but rather attempt to present what we view as a typical or common set of arguments. In presenting these sets of arguments and our subsequent discussion of them we focus purely on the housing foreseeability issue and will not address other important considerations that might affect the assessment of these arguments. ${ }^{4}$

\footnotetext{
${ }^{4}$ For instance, an important issue in assessing whether there was a disclosure deficiency is the "truth on the market” defense, i.e. the market already knew the truth that was supposedly concealed by the financial
} 


\section{A. Disclosure Deficiencies}

The claim that the housing market downturn that began in the fourth quarter of 2007 was foreseeable during the purported class period is typically used in a variety of ways to support the argument that the financial institution in question is responsible for a disclosure deficiency that is actionable under the securities laws. We will now present the standard ways in which purported disclosure deficiencies work off of the contention that the housing market downturn was foreseeable.

If the financial institution had substantial holdings of securities with exposure to the real estate market during the class period, a category that includes the vast majority of financial institutions named as defendants, then one of the primary disclosure deficiencies commonly asserted resides in the failure of the financial institution during the class period to fully disclose detailed information on the exact size of these security holdings as well as fully disclose the nature of these security holdings' exposure to the real estate market, such as whether the exposure was to subprime, Alt-A or prime borrowers. Moreover, the purported failure of a financial institution to fully disclose off-balance sheet exposures to securities tied to the real estate market, such as the provision of asset backed commercial paper (“ABCP”) liquidity puts (contractual guarantees by a financial institution to purchase $\mathrm{ABCP}$ under certain conditions) is also often pointed to as constituting an actionable disclosure deficiency. Security positions, off-balance sheet exposures, and the nature of the resulting exposure to the real estate market all constitute materially important information, so the argument continues, given the foreseeability of the housing market downturn and hence the likely losses the financial institution faced as a result.

The foreseeability of the housing market downturn is a crucial step in the argument for the existence of a disclosure deficiency as the mere fact that there was a statistically significant, substantial stock price drop associated with, say, a fourth quarter, 2007 announcement of losses on CDO positions with real estate exposure does not

institution. For a discussion of this issue, see Jennifer Bethel, Allen Ferrell and Gang Hu, "Legal and Economic Issues in Litigation Arising Out of the Credit Market Crisis of 2000-2008," forthcoming in Brookings. 
establish that information concerning these CDO positions should be viewed as "material" information during the purported class period which would be an earlier point in time. If the market cares about the size and nature of a financial institution's CDO positions in the fourth quarter of 2007 purely because of a downturn in the housing market at that time, or an expected downturn in the housing market at that time, then one would not expect information concerning the size and nature of a financial institution's CDO positions to necessarily be of importance at a point in time when the market did not have these housing market concerns. It is worth noting that the potential non-materiality of this information during the purported class period remains even if there were some observers during the purported class period whose views differed from that of the market's.

Another standard argument for why financial firms who reported large writedowns and losses in the fourth quarter of 2007 and first quarter of 2008 are responsible for disclosure deficiencies, and hence are liable for investors' losses, focuses on these firms' public disclosures of the value of their security holdings during the purported class period, again a period which often begins in 2006 or earlier. Even if a financial institution did not separately publicly disclose the value of specific holdings of securities throughout the purported class period, such as the value of its CDO positions, it is still nevertheless possible that these valuations were included in the calculation of a more aggregated value of the firm's security holdings that was released by the firm to the market during the purported class period. On a closely related note, a common claim is that larger reserves should have been taken in anticipation of future losses. Once again, the foreseeability of the housing market downturn will play a crucial role in the argument for why there was a disclosure deficiency as a result of these valuation disclosures or failure to establish sufficient reserves. If the downturn was foreseeable, and therefore so were the writedowns and losses on these security holdings and exposures that followed, then the alleged disclosure deficiency consists in the public disclosures of aggregate valuation figures that were improperly inflated as a result of a failure to incorporate the 
looming housing market downturn or the misleadingly low levels of reserves set aside in anticipation of future losses. ${ }^{5}$

In buttressing these two disclosure deficiency theories, or sometimes as a basis for concluding that there was another separate disclosure deficiency, there is often an extensive discussion by plaintiffs of the deteriorating underwriting quality of mortgages during the purported class period as measured by the credit quality of borrowers, and documentation thereof, in relationship to the types of mortgages borrowers were assuming (such as mortgages with adjustable rates or interest-only mortgages). This discussion forms the basis for the claim that the overall quality of the pools of mortgages against which securities were being issued was deteriorating sharply over time and, hence, the risks, which were purportedly not adequately disclosed, to financial institutions with exposures to these mortgages, whether via CDOs, ABCP or MBS. As before, the contention that there was a foreseeable housing downturn typically plays an important role in the discussion concerning deteriorating underwriting quality as it is the interaction of a housing market downturn and poor underwriting quality that is claimed to have led to the substantial writedowns and losses suffered by financial institutions. The reliance on this interaction effect implicitly recognizes that in a world of appreciating housing prices but poor underwriting quality, financial institutions' writedowns and losses would have been far less, perhaps largely non-existent, given the ability of the house itself to serve as a sufficient guarantee of payment.

In the context of ERISA class action litigation, litigation which forms an important component of the overall securities class action litigation being pursued against financial institutions, the alleged disclosure deficiency claim often consists of the argument that the ERISA fiduciaries improperly failed to disclose that investing in the firm's stock was an "imprudent” investment given the financial institution's exposure to securities whose value is substantially tied to the value of the real estate market. As with the other disclosure deficiency theories already discuss, this argument again typically

\footnotetext{
${ }^{5}$ Besides the foreseeability issue, there are other important issues that need to be taken into account in assessing this argument concerning valuation, including the appropriate accounting treatment used in generating publicly disclosed valuations (such as market-to-market versus market-to-model treatment in generating valuations). See, e.g., FASB 115 and 157.
} 
hinges on the foreseeability of the housing market downturn given the need to establish that this exposure was risky or likely to generate losses (and hence “imprudent”).

\section{B. Scienter for Disclosure Deficiencies}

A common, indeed standard, claim in the securities class action litigation is the contention that senior management at the financial institution in question recklessly accumulated positions or exposures to securities whose value was tied to the real estate market. The allegation of recklessness is often based on the further contention that senior management should have known or did in fact know that the value of these securities were likely going to fall, perhaps precipitously, given that it was foreseeable during the purported class period that the housing market was going to experience a serious downturn. These general statements concerning the predictability of future MBS, CDO and $\mathrm{ABCP}$ losses at a particular point in time due to the foreseeable downturn in the real estate market are sometimes calibrated to reflect the degree of subordination the security had (such as whether the security was in the super-senior, mezzanine or equity tranche) and the nature of the underlying exposure to the housing market (such as subprime, AltA, or prime mortgages). In other words, there is the recognition that even adopting the position that the housing market downturn was foreseeable, the resulting losses on MBS, CDO and ABCP exposures will also be a function of additional factors.

\section{Damages for Disclosure Deficiencies}

An issue that has become of central importance, particularly in the aftermath of the Supreme Court's 2005 decision in Dura Pharmaceuticals, Inc. v. Broudo ${ }^{6}$, is the necessity of establishing "loss causation” as a prerequisite for recovering damages in Rule 10b-5 actions. The "loss causation" is the requirement that the losses for which investors seek recovery must be traceable to the alleged disclosure deficiency. One formulation of the "loss causation" requirement is that losses must be attributable to the removal by a "corrective disclosure" of "inflation" that was present at the time of

\footnotetext{
${ }^{6} 544$ U.S. 336 (2005).
} 
purchase. "Inflation," in turn, is the difference between the actual price of the security and the price the security would have had but for the misconduct (the "but for world"), i.e. the price that would have obtained if the disclosure deficiency hadn't occurred. And a “corrective disclosure," as we have discussed at length in another article, is properly viewed as a disclosure that publicly reveals the firm's earlier misconduct to the market. ${ }^{7}$ In this connection it is worth noting that the Second Circuit in Lentell v. Merrill Lynch \& $\mathrm{Co}$, Inc. ${ }^{8}$ indicated that if a risk was fraudulently concealed by a firm, then the realization of that risk can serve as a corrective disclosure if such a realization unveils to the market the earlier actionable misconduct.

To establish loss causation it follows from the above discussion that it is insufficient to merely point to statistically significant, substantial price drops in reaction to a financial institution's announcement of writedowns and losses. The mere fact that a firm has bad news, even terrible news, does render the announcement of such news a revelation of earlier misconduct. To conclude otherwise would be reminiscent of the questionable "true financial condition" theory of loss causation in which a disclosure that reveals information concerning the firm's financial condition can be a corrective disclosure even if "no wrongdoing or error has been identified." ${ }^{9}$ Not surprisingly, this theory of loss causation has been increasingly rejected by courts. ${ }^{10}$ As a result the crucial move, once again, is the contention that these writedowns and losses were somewhat predictable at an earlier point in time given the foreseeability of the housing market downturn thereby rendering the failure by the financial institution to publicly discuss at an earlier point these potential losses, or at least the risk of these potential losses, fraudulent. The revelation of the writedowns and losses, according to this logic, can then serve as a corrective disclosure given that it was precisely this type of information that should have been revealed earlier but was fraudulently concealed.

\footnotetext{
${ }^{7}$ Allen Ferrell and Atanu Saha, "The Loss Causation Requirement for Rule 10B-5 Causes of Action: The Implications of Dura Pharmaceuticals v. Broudo,” 63 BusINESS LAWYER 163 (2007)

${ }^{8} 396$ F.3d 161.

${ }^{9}$ Madge Thorsen, Richard Kaplan and Scott Hakala, Recovering the Economics of Loss Causation, 6 J.Bus. \& Sec. L. 93, 102-103 (2006).

${ }^{10}$ See, e.g., Flowserve, 245 F.R.D at 574 ("The 'true financial condition' theory, if accepted, threatens to undermine the objective of securities law and disregards precedent”); In Re Retek, Inc. Securities Litigation, Civil No. 02-4209 (2009); cf. In re Omnicom Group, Inc., Sec. Litig., 541 F.Supp. 2d 546 (S.D.N.Y. 2008)
} 
Moreover, even if there was a negative stock price reaction (after controlling for market and industry effects) to a "corrective disclosure" only that portion of the negative stock price reaction that is attributable to the removal of "inflation" that was present at time of purchase should be recoverable consistent with the "loss causation" requirement. A negative firm-specific stock price reaction reflecting damage to the company's reputation, for instance, would not be attributable to the dissipation of "inflation" that was present at the time of investors' purchases. "Inflation” at the time of purchase would not include future reputational harm caused by a corrective disclosure given that "inflation" is measured by reference to the "but for world," the world in which the disclosure deficiency never occurred. In the "but for world" such reputational harm would not by definition have occurred. We labeled the non-recoverable portion of the negative stock price reaction in an earlier article "collateral damage."11

Besides the non-recoverability of "collateral damage" following from the standard definition of "inflation" there is a powerful economic reason to exclude such damages. As a result of the Supreme Court's decision in Blue Chip Stamps v. Manor Drug Stores ${ }^{12}$, it is well established that "holder claims," claims that include those filed by investors that purchased their shares prior to the actionable disclosure deficiency and held those shares through the corrective disclosure, cannot recover any damages. But holder investors suffer from "collateral damage," such as harm to a company's reputation, to the same extent as investors who purchased after the actionable disclosure deficiency and also held through the corrective disclosure. If the former set of investors cannot recover these damages, there is no reason to conclude that the latter set of investors should be able to. ${ }^{13}$ In contrast, investors who did purchase after the disclosure deficiency did suffer a particular harm which holder investors were not subject to, i.e. purchasing at an inflated price and thereafter suffering from the dissipation of that inflation. Holder investors are differently situated with respect to this harm because they purchased at a price that was not inflated.

\footnotetext{
${ }^{11}$ Allen Ferrell and Atanu Saha, "The Loss Causation Requirement for Rule 10B-5 Causes of Action: The Implications of Dura Pharmaceuticals v. Broudo,” 63 BusINEss LAWYER 163 (2007)

${ }^{12} 421$ U.S. 723 (1975)

${ }^{13}$ See Brad Cornell and Rutten, "Collateral Damage and Securities Litigation,” Working Paper, for a good discussion of the Blue Chips issue and the concept of collateral damage.
} 


\section{RELEVANT ACADEMIC LITERATURE}

A number of academic studies document that housing prices are a primary determinant of mortgage delinquencies and foreclosures, including the spike in delinquencies and foreclosures experienced in 2007 and 2008. This basic finding further highlights the central importance of when the housing market downturn became foreseeable. Indeed, there is substantial evidence in the academic literature that the decline in housing prices was in fact substantially more important as an explanatory factor for the spike in delinquencies and foreclosures in 2007 and 2008 than poor underwriting quality.

Perhaps the paper closest to ours is that of Gerardi, Lehnert, Sherland and Willen (2009) who examined whether market participants could have or should have anticipated the spike in foreclosures that occurred in 2007 and 2008. ${ }^{14}$ The paper finds that subprime mortgages originated in 2005-2006 were in fact not all that different from subprime mortgages made earlier. And these earlier vintages of subprime mortgages had in fact performed well. The paper also documents that the decline in housing prices was more important than other factors, including underwriter quality, in explaining the spike in foreclosures in 2007 and 2008. ${ }^{15}$ On the issue of underwriting quality, the paper further explains that, "One of our key findings is that most of the uncertainty stemmed from uncertainty about the evolution of house prices and not from uncertainty about the quality of the underwriting."

Finally, this paper found that market participants, such as analysts, during the 2004 - 2006 period widely predicted continued housing price appreciation, albeit appreciation at a more modest pace. In terms of the academic literature during the 2004 2006 time period on whether housing prices were in some sense overvalued, there was no consensus with different papers taking different positions on the issue (and adopting different measures of what constitutes “over-valuation”). ${ }^{16}$

\footnotetext{
14 See Kristopher Gerardi, Andreas Lehnert, Shane Sherland and Paul Willen, "Making Sense of the Subprime Crisis,” forthcoming in Brookings Papers on Economic Activity.

15 See, e.g., id. at 17 ("[E]ven with the worst combination of underwriting characteristics, the predicted default rate is about half of the actual default rate experienced by this group of loans.”)

${ }^{16}$ See, e.g., Himmelberg, Mayer \& Sinai, “Assessing high house prices,” Journal of Economic Perspectives (2005) (justifying high housing prices on economic fundamentals); McCarthy and Peach, "Are Home Prices the Next 'Bubble'," FRBNY Economic Policy Review 10(3) (2004) (similar) with J. Gallin, “The
} 
Mayer, Pence and Sherlund (2009) report "substantial evidence that declines in house prices are a key factor in the current problems facing the mortgage market." ${ }^{17}$ This paper also reports a number of interesting findings on underwriting quality over the 2003 - 2007 period. They found "little evidence that the rise in delinquencies through mid2008" was linked to "novel and complicated mortgages products." ${ }^{18}$ An example of a novel and complicated mortgage product was "short-term hybrid" mortgages that often employed two- or three-year teaser rates. Moreover, they document that the median FICO credit score for mortgages in subprime and Alt-A mortgage pools remained quite stable over the 2003 - June, 2007 time period with the median FICO credit score for subprime mortgages being 615 in 2003 and 613 during the January - June, 2007 period. The median FICO credit score for Alt-A mortgages in 2003 was 710 and 707 during the January - June, 2007 period. ${ }^{19}$

The importance of housing prices in explaining mortgage delinquencies and foreclosures is reflected in other papers. Gerardi, Shapiro and Willen (2007) found, based on the default behavior of a large detailed sample of Massachusetts homeowners tracked over time, that housing prices were the primary drivers of defaults. ${ }^{20}$ Sherlund (2008) found, based on the default behavior of subprime mortgages that were securitized over the 2000-2007 period, that "[h]ousing price appreciation seems to be the primary determinant of default and prepayment behavior." ${ }^{21}$

Consistent with the importance of the decline in housing prices in accounting for delinquencies and foreclosures are a series of academic studies that find that borrowers with negative equity in their home, i.e. the mortgage is larger than the value of the house, are more likely to default on their mortgage. These studies include those of Sherlund (2008) and Foote, Gerardi, and Willen (2008). ${ }^{22}$

\footnotetext{
long-run relationship between house prices and income: Evidence from local housing markets," 34 Real Estate Economics 417 (2006)

${ }_{17}$ C. Mayher, K. Pence and S. Sherlund, "The Rise in Mortgage Defaults," 23 Journal of Economic Perspectives 27 (2009).

${ }^{18}$ Id.

${ }^{19}$ Id. at Table 2, Panel C.

${ }^{20}$ Kristopher Gerardi, A. Shapiro, Paul Willen, "Subprime Outcomes: Risky Mortgages, homeownership experiences, and foreclosures," Federal Reserve Bank of Boston Working Paper 07-15.

${ }^{21}$ S. Sherlund, "The Past, Present and Future of Subprime Mortgages,” Working Paper (2008).

${ }^{22}$ C. Foote, K. Gerardi, and P. Willen, "Negative Equity and Foreclosure: Theory and Evidence," 64 Journal of Urban Economics 234 (2008).
} 


\section{ANALysis OF ForeseEABILITY: Housing DATA}

We will begin our analysis of housing data by examining in Section A housing prices, both changes in monthly nationwide housing prices as well as monthly changes on a regional basis. This analysis will show that the sustained housing market downturn began in September of 2007 and continued throughout the fourth quarter of 2007. In contrast, the housing price declines in the fourth quarter of 2006 and January of 2007 were more modest and quickly abated (as had happened in the past with nationwide housing downturns) until September of 2007.

As a result, the issue is whether the housing market downturn that began in September of 2007 was foreseeable. We address this issue in a number of ways using housing data. In addition to examining the course of housing prices nationwide and regionally, Section A also calculates the likelihood of the September - December 2007 housing downturn occurring based on historical housing pricing movements. Section B then addresses the probability of a housing market downturn occurring using historical housing sales data. Finally, Section C presents evidence of the market's expectations of future housing prices based on the prices of housing price futures traded on the Chicago Mercantile Exchange (CME). We view this evidence as particularly powerful as this constitutes direct evidence of what sophisticated market participants, with their own money at stake, believed about the future of housing prices. All three sets of analyses using various types of housing data are consistent with the housing market downturn that began in September of 2007 not being generally foreseen by the market.

\section{A. Housing Prices}

\section{Nationwide Housing Prices}

Figure 3 below graphs the history of year-over-year changes in monthly nominal nationwide housing prices, beginning with January 1969 as this was the first month such data are available, and the statistical significance of these changes. ${ }^{23}$

\footnotetext{
${ }^{23}$ Given that housing price data are available on a regional basis (Northeast, Midwest, South and West) we calculated a nationwide housing price series by weighting the regional data. The regional weights were
} 
Figure 3

Year-Over-Year Change in Monthly Housing Prices January 1969 - September 2008

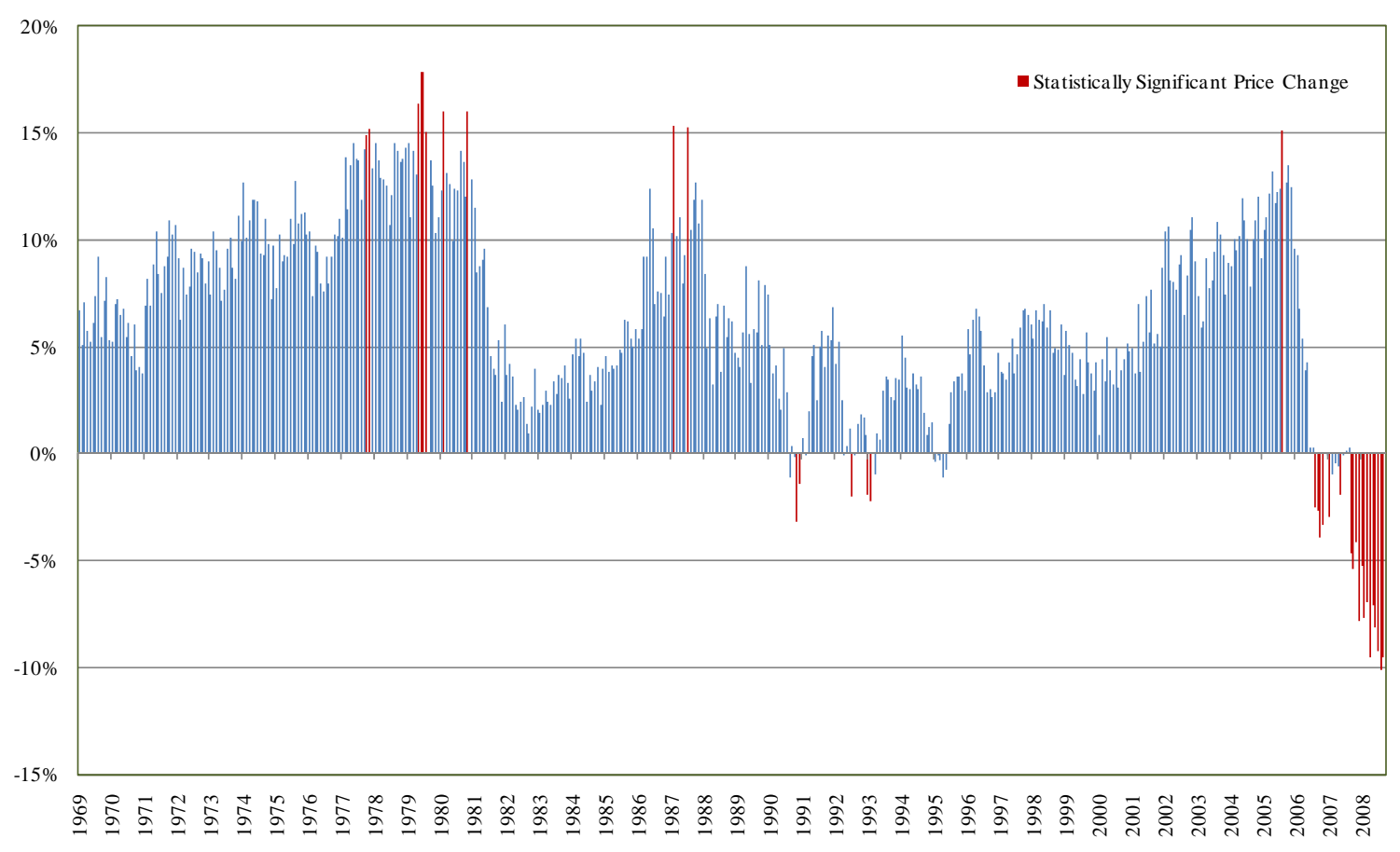

Note: Housing prices are a weighted average of the prices of Northeast (22\%), Midwest (22\%), West (28\%), and South (28\%). Source: Housing prices used are Median Existing Single Family Home Prices retrieved from National Association of Realtors.

One basic fact, well-recognized in the academic literature on housing prices, is readily apparent from Figure 3. Prior to 2006, nationwide price declines were quite rare with such declines occurring with statistical significance in only five months (November and December 1990; July 1992; and January and February of 1993) with the trend quickly reversing itself after such declines. Indeed, even during the deep recession of 1981-1982 housing prices did not fall nationwide. Rather, consistent with the observations of Case (2008) ${ }^{24}$ that the housing market has historically cleared through drops in housing sales (and starts) rather than reductions in price (a "quantity-clearing market”), the market cleared during the 1981-1982 recession, as Figure 5 will document, by a dramatic fall in housing sales.

calculated using optimal portfolio theory, which maximizes the mean-variance objective function. Statistical significance was calculated using the standard deviation of monthly year-over-year changes for the period January 1969 - December, 2005.

${ }^{24}$ K. Case, "The Central Role of House Prices in the Financial Crisis: How will the Market Clear?," Brookings Papers on Economic Activity. 
The nominal year-over-year changes in monthly housing prices for the subperiod of January 2006 - September 2008 is reported in Figure 4 below.

Figure 4

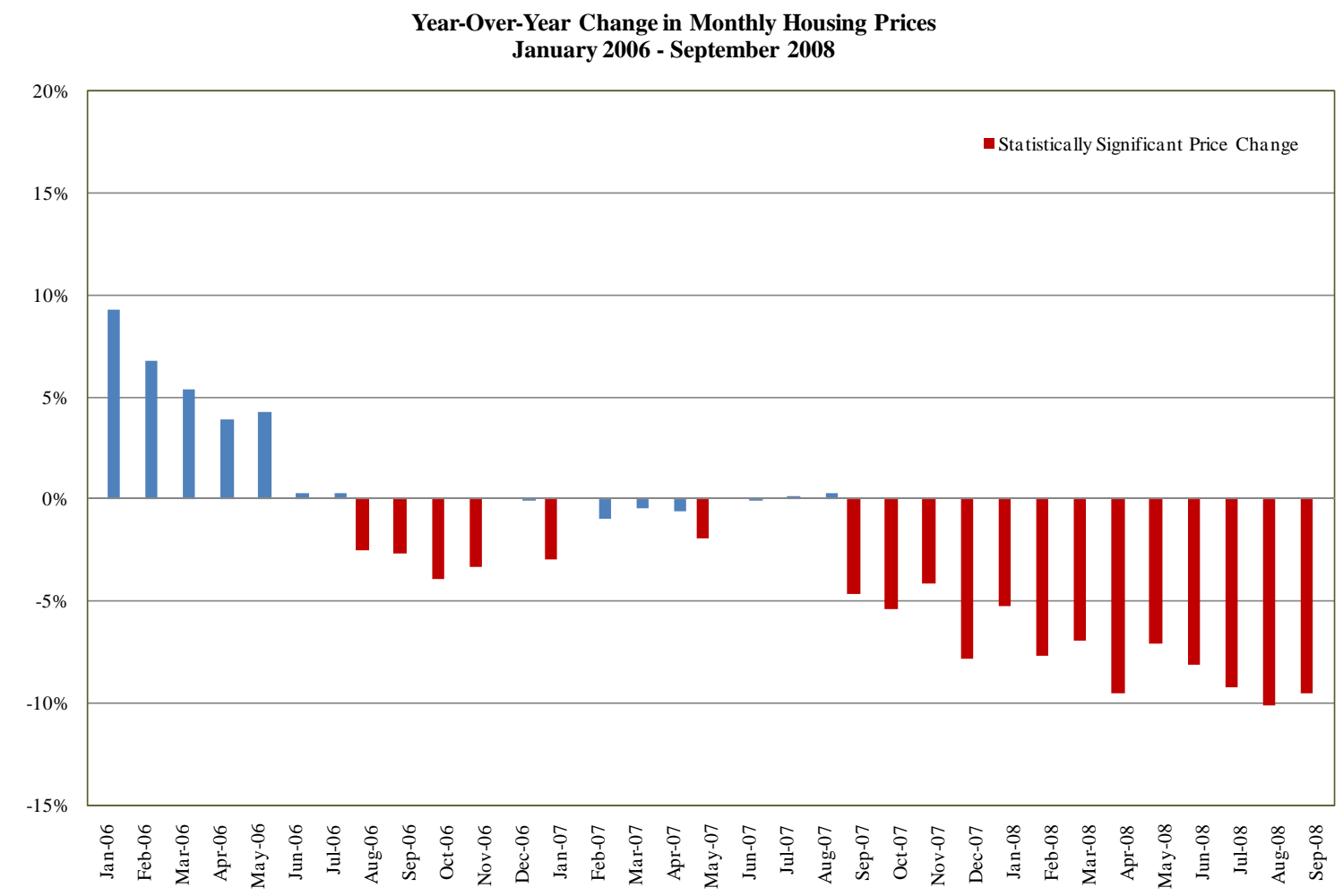

Note: Housing prices are a weighted average of the prices of Northeast (22\%), Midwest (22\%), West (28\%), and South (28\%). Source: Housing prices used are Median Existing Single Family Home Prices retrieved from National Association of Realtors.

Figure 4 documents that there were nationwide housing price declines during the four months of August, 2006 - November, 2006, with the very modest decline in December, 2006 not being statistically significant, and a further decline in January of 2007. These declines were similar in magnitude to those that had occurred in the five months during the 1990s that also experienced statistically significant nationwide housing declines and which had quickly reversed themselves. The subsequent February, 2007 - August, 2007 time period was essentially flat. Based on this reversal of the downward trend in prices, it would have been perfectly rational for financial institutions, during that point in time, to expect that the worst was over and a recovery in the housing market was on its way. Indeed such short-lived periods of price declines were the norm in the past forty years. As Figure 4 shows, the months of July and August 2007 did in fact experience positive 
changes in prices, further bolstering the expectation of a recovery. However, we now know looking back in time, such expectations turned out to be untrue.

Nationwide housing prices began to fall on a substantial and sustained basis in September of 2007 and continued unabated throughout the fourth quarter of 2007 (and beyond). It was these housing market declines, and specifically the housing price declines in the fourth quarter of 2007 (two out of these three months experienced declines in excess of 5\%) that were simultaneous with the large writedowns and losses announced by financial institutions in the fourth quarter of 2007.

It is clear from Figure 4 that the statistical significance of the changes in monthly housing prices only became statistically significant on a sustained basis (with some price monthly declines exceeding 5\%) starting in September of 2007 with housing price changes during the summer of 2007 not being statistically significant (and which where virtually flat in any event).

\section{Regional Housing Prices}

Turning to the regional data on year-over-year changes in monthly housing prices, we investigated the extent to which these regional housing price changes tend to be correlated. Table I documents that over the January, 1969 - December, 2006 period the incidence of all four regions (again defined as the Northeast, Midwest, South and West) simultaneously experiencing a drop in housing prices was exceedingly low at $0.4 \%$. Even a synchronized housing drop among three of the four regions was quite rare with an incidence of just 2\%. In contrast, as is documented in Table II, all four regions for September of 2007 as well as for all three months in the fourth quarter of 2007 (October, November and December) experienced a simultaneous drop in housing prices.

Once again, this analysis is consistent with the view that the housing dowturn that began in September of 2007 was serious, sustained and, if one were to use historical housing data, unexpected. 


\section{B. Housing Sales}

Figure 5 presents housing sales figures starting in January, 1969 till September of 2008 along with the mean of the positive monthly housing sales and the mean of the negative housing sale figures during this period.

Figure 5

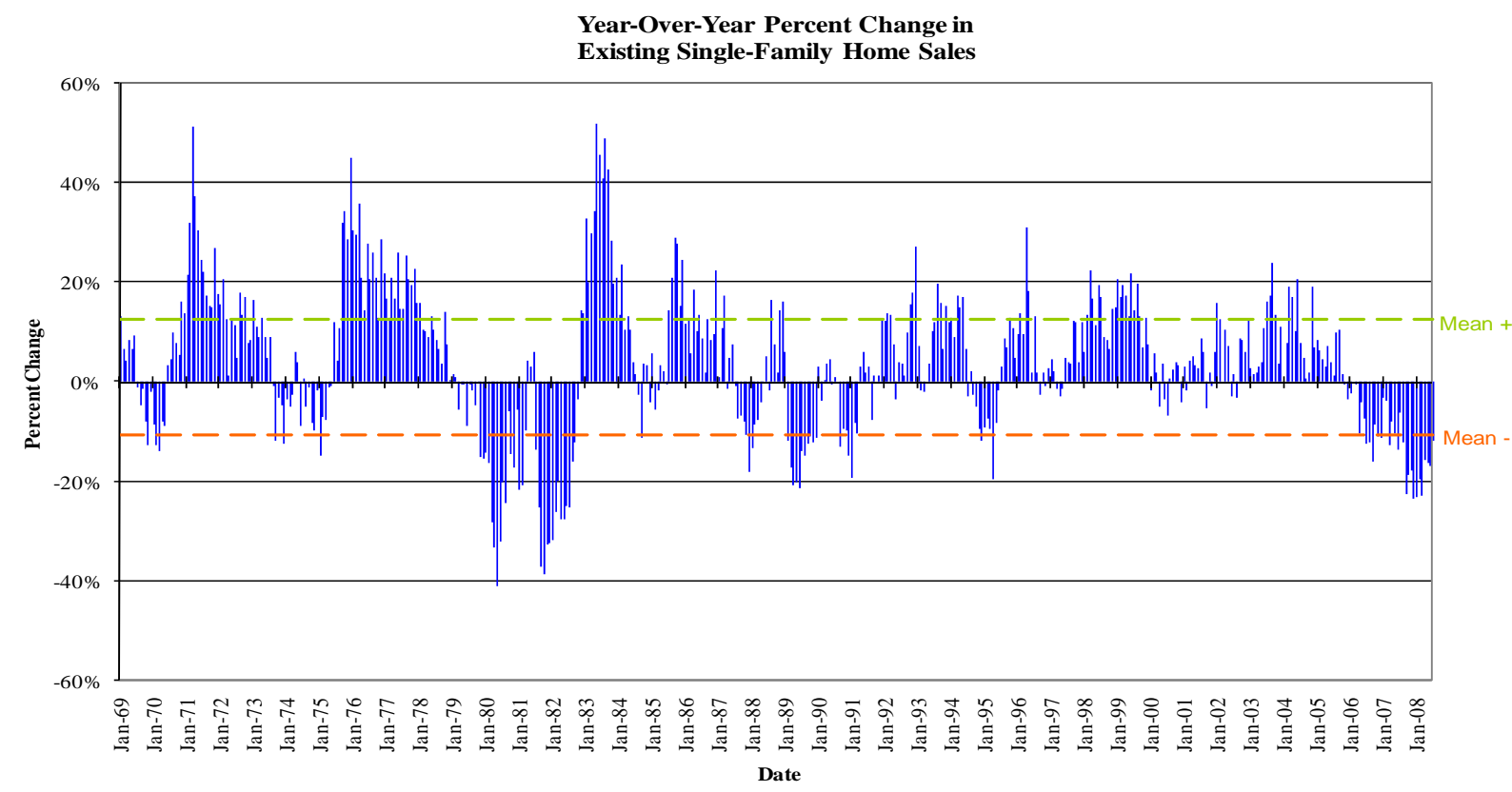

Notes and Source:

[1] Mean + is the average of all positive returns and Mean - is the average of all negative returns. This calculation uses the year-over-year percent changes from January 1969 - July 2008 [2] National Association of Realtors

Consistent with Case's (2008) observations, there has been in times of economic stress a substantial drop in housing sales. This is particularly noticeable in Figure 5 during the double dip recessions of the early 1980s (1980 and 1981-1982). There were also noticeable falls in housing sales in other times of economic stress, including the recessions of 1974-1975, 1990-1991 and the current time period.

As can be seen in Figure 6, which focuses on the 2000-2008 sub-period, the decline in housing sales in the current time period substantially accelerated starting in September of 2007. In contrast, the decline in housing sales in the fourth quarter of 2006 remained close to the historical mean of negative housing sales figures. 
Figure 6

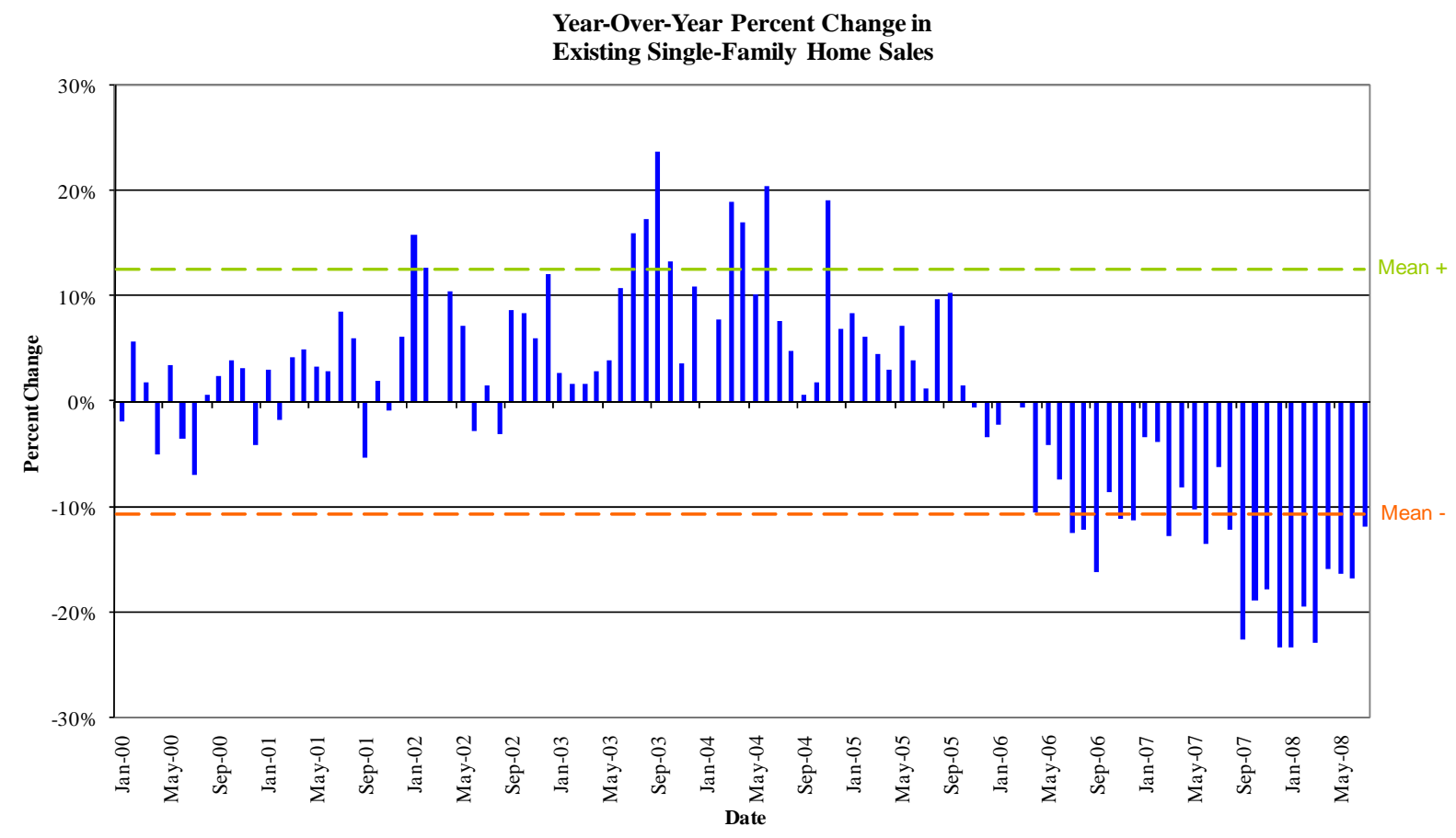

Notes and Source:

[1] Mean + is the average of all positivereturns and Mean - is the average of all negative returns. This calculation uses the year-over-yearpercent changes from January 1969 - July 2008. 2] National Association of Realtors

Given the importance of changes in housing sales as the primary means by which the housing market has historically cleared in times of economic stress, we examined the relationship between year-over-year percentage changes in monthly housing sales (our dependent variable) over the January, 1969 - December, 2005 time period and, as independent variables, year-over-year percentage changes in: the U.S. unemployment rate, the production level of the purchasing managers' index, the 10-year U.S. Treasury rate and, finally, whether the country was in recession. ${ }^{25} \mathrm{~A}$ description of these variables can be found in Table III and the regressions results in Table IV. We have then used the historical relationship of monthly housing sales with these independent variables as identified by our regression analysis to predict the housing sales changes for the 'insample' period of 1969-2005 and for the 'out-of-sample' period of 2006-2008.

The results of this analysis are reflected in Figure 7

\footnotetext{
${ }^{25}$ We use an indicator variable that takes a value of one for each of the months identified by NBER as recessionary.
} 
Figure 7

Year-Over-Year Percent Change in Existing Single-Family Home Sales $1969-2008$

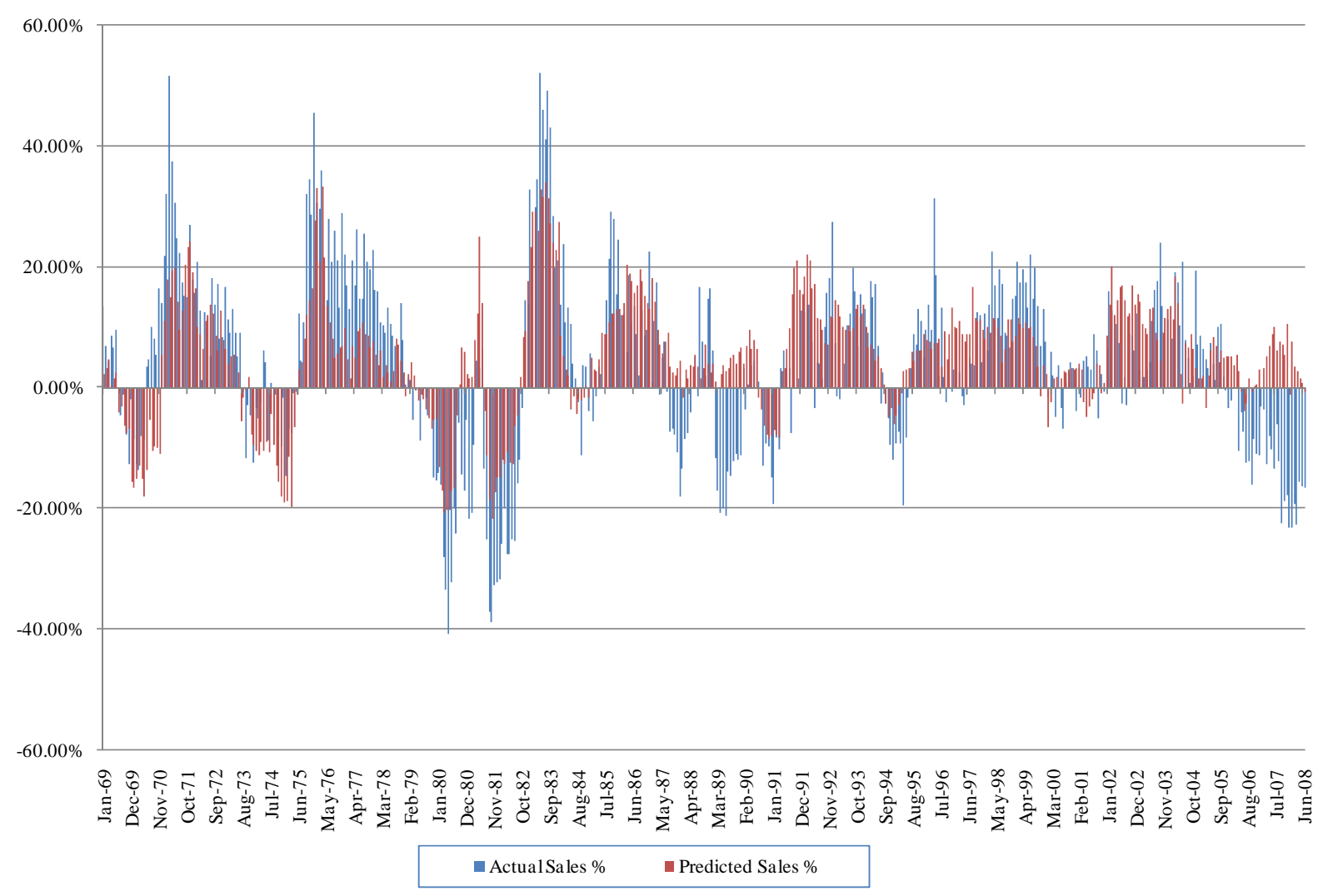

Figure 7 suggests that the key macro-economic variables do a fairly nice job (with an adjusted $\mathrm{R}^{2}$ of $48 \%$ ) of predicting the movements in the housing sales. However, these variables fail to predict the severe downturn in sales, particularly in the fall of 2007. The results presented in Table IV show that statistically significant deviation between modelpredicted sales changes (which are positive) and actual sales changes (which are negative) occurred for seven consecutive months between September 2007 and March 2008. Thus, based on the historical relationship between the macro-economic variables and housing sales one would not have predicted the severe sales downturn in 2007. Again these results are consistent with the statistical significant declines in the housing prices we discussed earlier. 


\section{Housing Futures Data}

Perhaps the most powerful evidence concerning what was in fact expected by market participants is pricing data on housing futures which were traded by large, sophisticated institutional investors on the CME. These were three-month forward looking contracts. It is bears emphasis that these investors stood to lose their own money if their prediction about future housing prices were incorrect and therefore had an incentive to accurately predict the future course of housing prices. Figure 8 plots the value of the CME housing futures contracts starting in August of 2006 when these contracts first traded.

Figure 8

Historical CME Housing Futures - Compsite Index

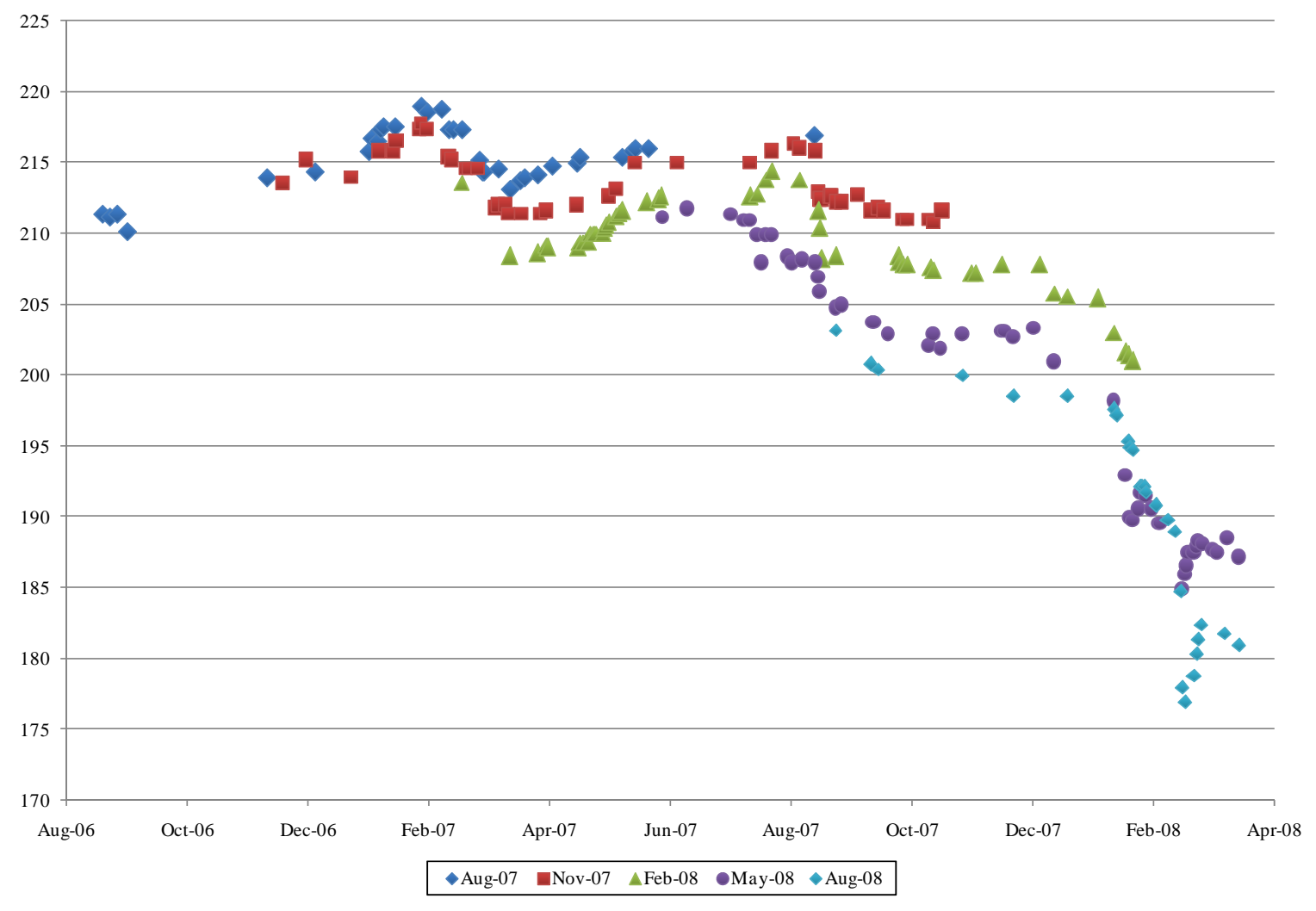

It is readily apparent from Figure 8 that during the fourth quarter of 2006 and first quarter of 2007 market participants in the CME housing futures market did not anticipate 
a decline in housing prices. Rather, what is observed is relative stability in market expectations until a decline in the fourth quarter of 2007 and then a precipitous drop at the very end of 2007 and beginning of 2008.

\section{ANALysis OF ForeseEABILITY: MARKET SPREADS}

A variety of spreads that track market conditions are consistent with the period prior to the summer of 2007, including the fourth quarter of 2006 and first quarter of 2007, being largely devoid of general market turmoil. Many of these spreads indicate that the sharp deterioration in the markets first occurred during the summer of 2007 (and, importantly, for some spreads the initial sharp deterioration only occurring well into the fall of 2007). A number of these spreads also indicate that there was a partial recovery in September of 2007 with another sharp deterioration in market conditions occurring in November and December of 2007. To the extent that these various market spreads impact or reflect the market's valuation of securities with substantial real estate exposure, these spreads can be useful, if analyzed appropriately, in assessing when the market began to anticipate the housing market downturn as an anticipated housing market downturn could well affect any such valuation (of course taking into account other factors, such as the level of subordination).

One much commented upon market spread is the three-month TED spread which is a measure of the cost to large banks of borrowing funds from other banks on a shortterm, unsecured basis. More specifically, the three-month TED spread is the difference between the three-month London Interbank Offering Rate (which tracks the cost of funds in the unsecured London interbank lending market) and the three-month U.S. treasury bill rate (used as a proxy for the risk-free rate). The TED spread was largely flat from the beginning of 2006 (and indeed before then as well) till the summer of 2007. In June of 2007, there was a relatively modest increase in the TED spread, a return to more normal levels in July, 2007, and then a dramatic spike in the spread occurring on August 9, 2007. The TED spread made a partial recovery in September of 2007 to more normal levels but again steadily and dramatically worsened in November and December of 2007. The general pattern is therefore one of market stability till August of 2007, partial recovery in 
September of 2007, and then substantial deterioration in the fourth quarter (October December, 2007). ${ }^{26}$

One can see a broadly similar pattern if one looks at the difference between the yield on thirty-day A2/P2 commercial paper yield and thirty day AA-rated non-financial commercial paper. This spread is one measure for tracking the yield premium required by the market for purchasing low-rated (A2/P2) commercial paper relative to high-rated (AA) non-financial commercial paper. This spread, like the three-month TED spread, deteriorated sharply in August of 2007, staged a partial recovery in September of 2007 and shortly thereafter experienced another sharp deterioration well into December of 2007. The A2/P2 spread is depicted in Figure 9 below.

Figure 9

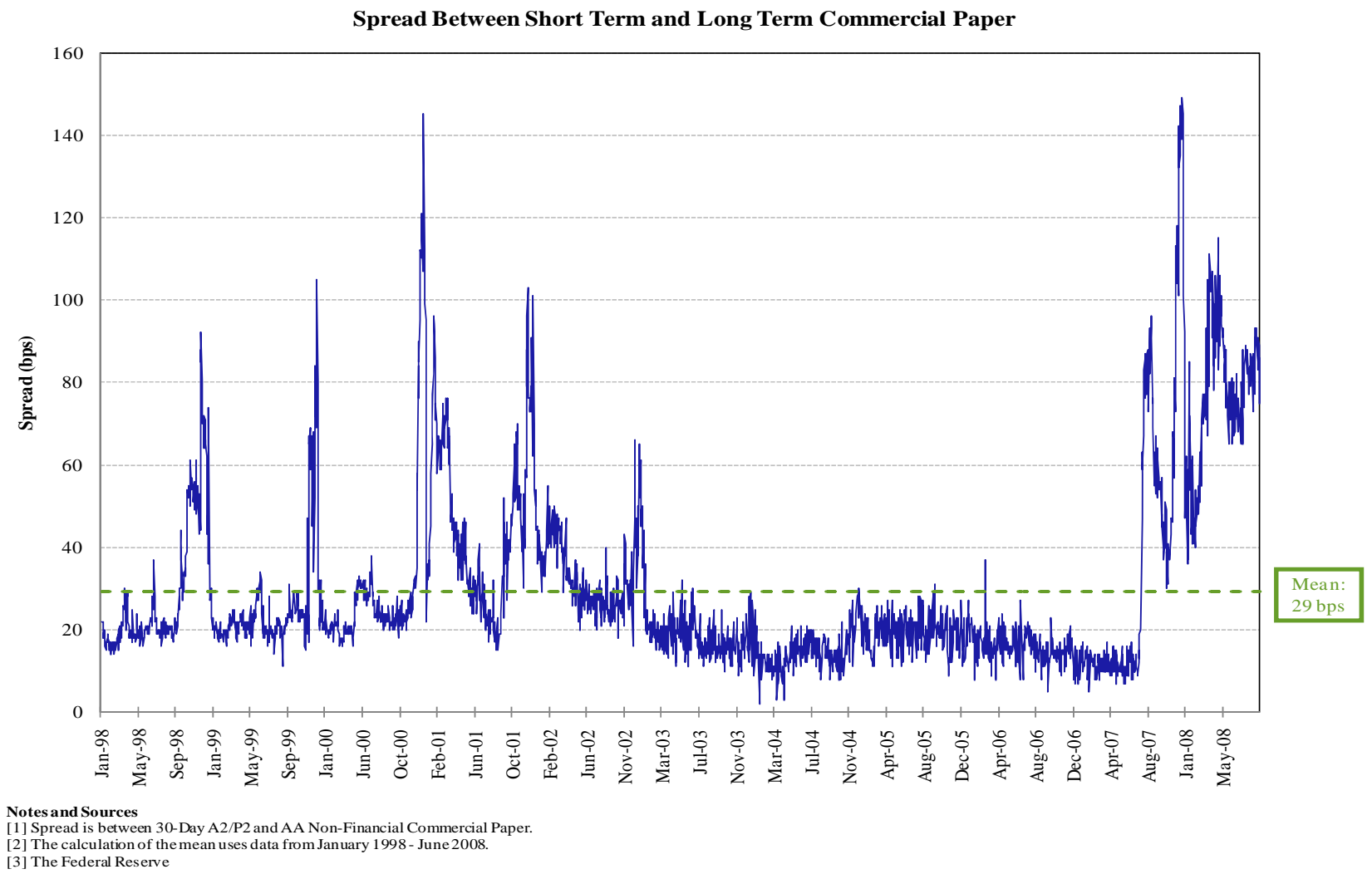

\footnotetext{
${ }^{26}$ Other commentators have similarly characterized the sequence of events in the second half of 2007. See, e.g., Stephen Cecchetti, "Monetary Policy and the Financial Crisis of 2007-2008”, Working Paper, p.15 ("Starting in early August risk spreads abruptly widened. Then, through late September and early November, things looked as if they were calming down. At the end of November, as both the year end approached and it became clear that financial institutions were experiencing large losses, conditions worsened, and continued to deteriorate into the winter of 2008.”)
} 
If one were to examine the credit default swap spreads (which proxy for the risk of default on a firm's debt against which the swaps are written) for the commercial and investment banks, one would once again observe a sharp increase in these spreads in August of 2007, a substantial narrowing of the spreads in September, and then another sharp increase in the second half of October of 2007 and continuing through the remainder of the year.

A market spread of particular note are the values of various ABX indexes that are often pointed to as at least potential indicators of the value of MBS of various ratings (triple $A$ and so forth) and vintages. Figure 10 below presents the value of various $A B X$ indexes related to triple A rated MBS of different vintages.

Figure 10

ABX.HE AAA Closing Prices since Jan 2007

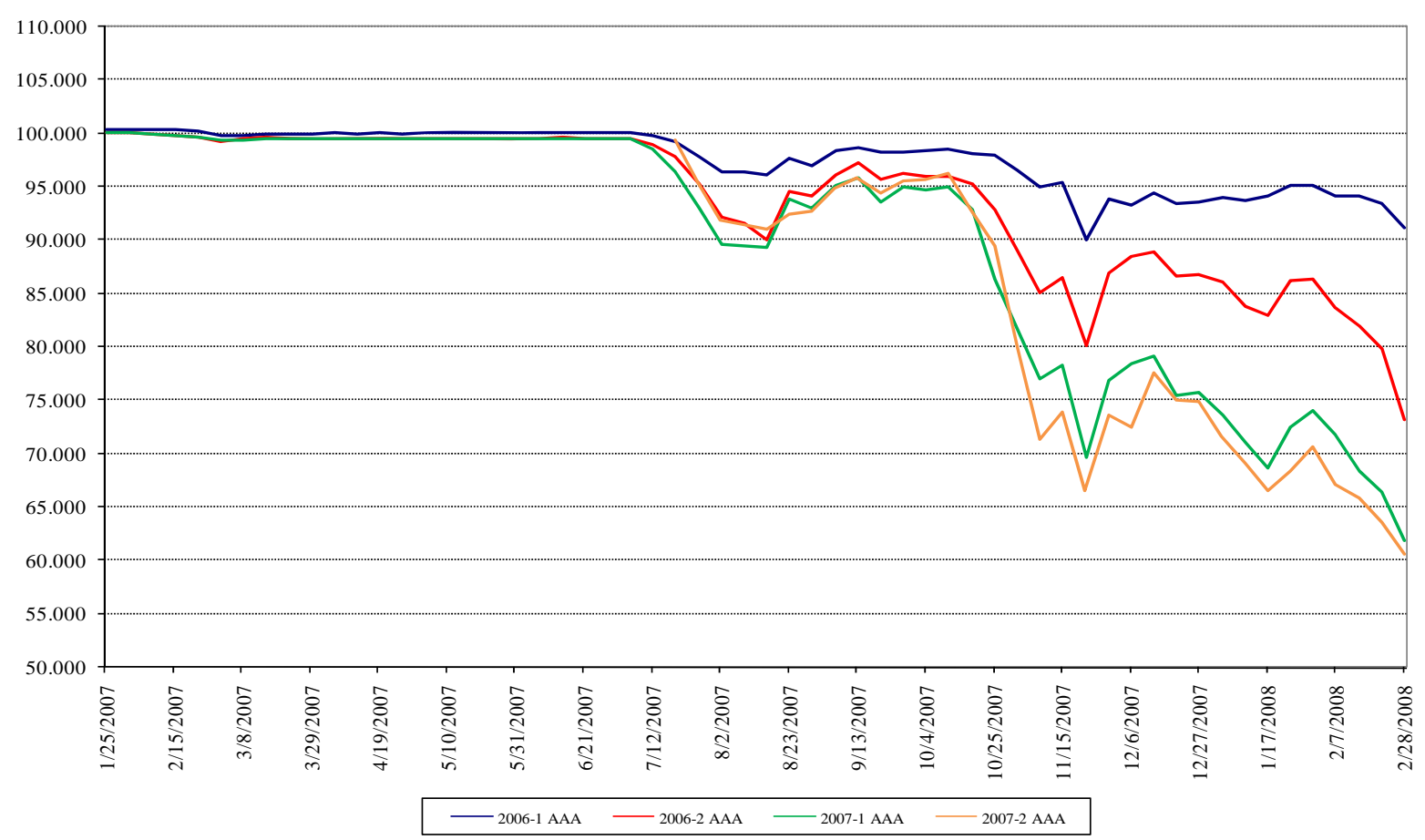

As is clear from Figure 10, the value of the ABX indexes associated with triple A MBS does not experience a sharp deterioration until the second half of October of 2007. While there was a relatively modest dip experienced in late July and August of 2007, 
most of the lost value was recovered by September of 2007. This is of particular importance because many of the securities with substantial real estate exposure that resulted in the writedowns and losses announced by financial institutions beginning in the fourth quarter of 2007 were rated triple A (or were "super seniors" which were considered even better than mere triple A). The loss in value for many of the $A B X$ indexes continued to decline at a rapid pace in January and February of 2008.

We conclude from our examination of these market spreads that there is little indication that the market was anticipating during the course of 2007 the serious housing market downturn that in fact occurred in the fourth quarter of that year. And, after the market disruptions experienced in August of 2007, there was an apparent stabilization of market conditions in September of 2007 with much of the serious downturn in many of these market spreads only resuming in the fourth quarter (and for the $\mathrm{ABX}$ triple $\mathrm{A}$ indices, only really beginning their initial serious fall in value in the fourth quarter).

\section{CONCLUSION}

When the serious housing market downturn, which began in September of 2007 and continued throughout the remained of 2007 (and beyond), was foreseen will be one of the centrally contested issues in the securities class action litigation that has been filed against a large swathe of financial institutions. The foreseeability of the housing market downturn plays a key role in the standard arguments by plaintiffs for why there were disclosure deficiencies, scienter for those disclosure deficiencies and loss causation for the sizable economic losses suffered by investors in financial institutions.

Based on our own analysis of housing price data, including housing prices, housing sales and housing futures prices as well as various market spreads, we conclude that the evidence is consistent with the proposition that the serious housing market downturn was not generally foreseeable and was not foreseen by sophisticated market participants prior to the fourth quarter of 2007. Indeed, market conditions were relatively benign till the summer of 2007 with partial normalization of conditions prevailing in until early fall of 2007 in the aftermath of the summer shocks. More specifically, we conclude that the evidence is consistent with the housing market downturn not generally being foreseen in the fourth quarter of 2006 or the first quarter of 2007. 


\section{Table I}

\section{Observed Occurrence of Negative \\ Year-Over-Year Housing Price Changes \\ January 1969 - December 2006}

\section{Panel A: Frequency per Individual Region}

\begin{tabular}{cc}
\hline Regions & Frequency \\
\hline Northeast & $14.5 \%$ \\
Midwest & $3.9 \%$ \\
South & $6.6 \%$ \\
West & $10.3 \%$ \\
\hline
\end{tabular}

Panel B: Frequency of Multiple Regions per Month

\begin{tabular}{ccc}
\hline $\begin{array}{c}\text { \# of Regions } \\
\text { with Negative } \\
\text { Change }\end{array}$ & Frequency & $\begin{array}{c}\text { Same as Getting \# of } \\
\text { Heads in a Row in } \\
\text { Coin Toss }\end{array}$ \\
\hline 0 & $75.9 \%$ & - \\
1 & $15.8 \%$ & 3 \\
2 & $5.9 \%$ & 5 \\
3 & $2.0 \%$ & 6 \\
4 & $0.4 \%$ & 8 \\
\hline
\end{tabular}

Source: Housing prices used are Median Existing Single Family

Home Prices retrieved from National Association of Realtors. 
Table II

Months with all 4 Regions

Illustrating Negative

Year-over-Year Housing Changes

\begin{tabular}{lll}
\hline \multicolumn{2}{l}{ Month } & Year \\
1. September & 2006 \\
2. November & 2006 \\
3. January & 2007 \\
4. & September & 2007 \\
5. & October & 2007 \\
6. & November & 2007 \\
7. December & 2007 \\
8. April & 2008 \\
9. May & 2008 \\
10. July & 2008 \\
11. August & 2008 \\
12. September & 2008
\end{tabular}




\section{Table III \\ Description of Regression Analysis}

- Dependent Variable:

- Existing Single-Family Housing Sales for the U.S. (Year-over-Year \% change)

as published by the National Association of Realtors on the 25th day of each month

- Independent Variables:

- U.S. Unemployment Rate (Year-over-Year \% change) as published by the Bureau of Labor Statistics measures employment and unemployment (of those over 15 years of age) using two different labor force surveys conducted by the United States Census Bureau and/or the Bureau of Labor Statistics that gather employment statistics monthly.

- Production level of Purchasing Managers' Index (Year-over-Year \% change) as published by the Institute for Supply Management and is a monthly composite index of five sub-indicators (production level, new orders, supplier deliveries, inventories and employment level) based on surveys to more than 400 purchasing managers from around the U.S.

- 10-Year US. Treasury Rate (Year-over-Year \% change).

- Months of Recession (dummy variable) as maintained by the National Bureau of Economic Research and is a chronology of U.S. business cycles and identifies the dates of peaks and troughs that frame economic recession or expansion.

- Regression Output:

- Predict future Existing Single-Family Housing Sales based on the historical relationship between the above independent and dependent variables

- In-sample period for regression analysis: January 1969 through December 2005 (444 months).

- Out-of-sample period for prediction: January 2006 through June 2008 (30 months).

- Comparison of actual Year-over-Year \% change in housing sales to predicted Year-over-Year \% change for the entire in- and out-of-sample periods (474 months). 


\section{Table IV}

\section{Regression Results and Significant Negative Error Months}

Panel A

\begin{tabular}{lrr}
\hline \multicolumn{1}{l}{ Regression results } & \\
\hline R Square & 0.488 & \\
Adjusted R Square & 0.483 & \\
Standard Error & 0.102 & \\
Observations & 444 & \\
\hline \multicolumn{2}{l}{ Coefficients } & \multicolumn{1}{c}{ t Stat } \\
\hline Constant & 0.059 & 10.686 \\
Unemployment Rate & -0.056 & -1.751 \\
Purchasing Managers Index (PMI) & 0.291 & 12.340 \\
10 year Treasury Bill & -0.340 & -10.595 \\
Recession & -0.073 & -4.227 \\
\hline
\end{tabular}

Panel B

Statistically significant and negative error months out of a total of 474 months

\begin{tabular}{|c|c|c|c|c|c|c|c|c|c|}
\hline & \multicolumn{6}{|c|}{ Months } & & & \multirow{2}{*}{$\frac{\text { Coun }}{6}$} \\
\hline Early 1980s & May-80 & Oct-80 & Nov-80 & Jan-81 & Feb-81 & May-81 & & & \\
\hline Late $1980 \mathrm{~s}$ & Dec-87 & Apr-89 & May-89 & Jun-89 & & & & & 4 \\
\hline Early 1990 s & Aug-91 & Oct-91 & May-92 & Apr-95 & & & & & 4 \\
\hline Late $2000 \mathrm{~s}$ & Jun-07 & Sep-07 & Oct-07 & Nov-07 & Dec-07 & Jan-08 & Feb-08 & Mar-08 & 8 \\
\hline$\overline{\text { Total }}$ & & & & & & & & & 22 \\
\hline
\end{tabular}

Notes:

[1] Error is defined as the difference between the actual sales percent change and the predicted sales percent change.

[2] Statistically significant error is defined as months where the error divided by the standard error of regression is less than -1.96. 